\title{
Yield of 'Royal Gala' apple trees in response to pruning before or after leaf drop
}

\author{
Gustavo Klamer de Almeida(1) and João Caetano Fioravanço(2)
}

(1)Universidade Federal do Rio Grande do Sul, Avenida Bento Gonçalves, o 7.712, CEP 91540-000 Porto Alegre, RS, Brazil.
E-mail: gklalmeida@hotmail.com (2)Embrapa Uva e Vinho, Rua Livramento, o 515, CEP 90701-008 Bento Gonçalves, RS, Brazil.
E-mail: joao.fioravanco@embrapa.br

Abstract - The objective of this work was to evaluate different pruning times, performed before or after natural leaf drop, regarding their effects on the yield of 'Royal Gala' apple (Malus domestica) trees. The experiment was carried out in Vacaria, in the state of Rio Grande do Sul, Brazil, on seven-year-old trees in four harvests from 2008/2009 to 2011/2012, using a randomized block design. The following pruning times were tested: 46 days before leaf drop (DBLD); 25 DBLD; 5 DBLD; 15 days after leaf drop (DALD); 36 DALD; 55 DALD; and 75 DALD. All pruning times before natural leaf drop reduced yield per tree and fruit set. Among the pruning times before leaf drop, 46 DBLD resulted in the lowest yield. Pruning performed after natural leaf drop, still during dormancy, resulted in a higher yield per tree, in comparison with pruning times before leaf drop. The effect of pruning times on average fruit mass, pulp firmness, content of soluble solids, titratable acidity, and soluble solids/titratable acidity ratio differed between harvest years. Pruning performed at different times, before natural leaf drop, causes yield reduction in 'Royal Gala' apple trees, and the pruning time at 46 DBLD results in the lowest yield.

Index terms: Malus domestica, fruit set, pruning time.

\section{Produção de macieiras 'Royal Gala' em resposta à poda antes ou depois da queda das folhas}

Resumo - O objetivo deste trabalho foi avaliar diferentes épocas de poda, antes ou depois da queda natural das folhas, quanto a seus efeitos sobre a produção de macieiras 'Royal Gala' (Malus domestica). O experimento foi realizado em Vacaria, RS, em plantas com sete anos de idade, em quatro colheitas de 2008/2009 a 2011/2012, tendo-se utilizado um delineamento experimental em blocos ao acaso. As seguintes épocas de poda foram avaliadas: 46 dias antes da queda de folhas (DAQF); 25 DAQF; 5 DAQF; 15 dias depois da queda de folhas (DDQF); 36 DDQF; 55 DDQF; e 75 DDQF. Todas as épocas de poda antes da queda natural de folhas reduziram a produção por planta e a frutificação efetiva. Entre as épocas de poda antes da queda de folhas, a de $46 \mathrm{DAQF}$ resultou na menor produção. As podas realizadas após a queda natural de folhas, ainda durante a dormência, resultaram em maior produção por árvore, em comparação aos períodos de poda antes da queda das folhas. $\mathrm{O}$ efeito das épocas de poda sobre a massa média de fruto, a firmeza de polpa, o teor de sólidos solúveis, a acidez titulável e a relação sólidos solúveis/acidez titulável diferiu entre as safras. Podas realizadas em diferentes períodos, antes da queda natural de folhas, causam a redução da produção de frutos em macieiras 'Royal Gala', e a poda aos $46 \mathrm{DAQF}$ resulta em menor produção.

Termos para indexação: Malus domestica, frutificação efetiva, época de poda.

\section{Introduction}

Pruning is one of the main management practices in the farming of fruit trees (Demirtas et al., 2010). Plant physiological responses to pruning can be affected by environmental factors such as temperature, luminosity, and water availability; by plant-related factors such as cultivar, age, and nutritional status; and by pruninginherent factors, such as time of execution, type, and intensity (Wünsche \& Lakso, 2000; Li et al., 2003).
Leaf removal by pruning during the growth cycle reduces the carbohydrate and nutrient accumulation in the remaining organs, and can reduce the growth of shoots and roots (Loescher et al., 1990; Ikinci, 2014). The rate of carbohydrate destined for fruit production is an essential factor for apple production, together with the capacity for photosynthetically active radiation (PAR) interception and the capacity for PAR conversion of chemical energy (Wünsche \& Lakso, 2000). Therefore, when pruning is performed too early, 
that is, prior to the natural leaf drop, it can be harmful due to the leaf area elimination, and also to the loss of carbohydrate stored in the shoots. This may have a negative impact on apple production in the subsequent year because the growth resumption after the dormancy period depends on carbohydrate and nitrogen stores, which are derivatives of the photosynthetic activity from the previous year (Loescher et al., 1990; Greer et al., 2002).

Pruning is usually performed during the dormancy period, which occurs after the leaf drop, since it allows more time for plants to accumulate reserve substances, besides establishing a balanced situation between vegetative and reproductive growth, favoring light penetration inside the canopy (Moatamed, 2012; Mohammadi et al., 2013; Ashraf \& Ashraf, 2014).

In other fruit trees of temperate climates, such as peach trees, the winter pruning has been reported to cause a lower yield than pruning performed after harvest; however, it has resulted in a greater regularity of production (Gonçalves et al., 2014). Nonetheless, other studies have shown that winter pruning promoted a similar yield to pruning before or after harvest (Ikinci, 2014; Ikinci et al., 2014). In plum trees, the summer pruning was more effective in reducing the formation of vigorous branches, also encouraging the growth of fruiting branches in comparison to the winter pruning (Sosna, 2010). In pear trees, different pruning times in the period close to harvest induced differences in the fruit set and in the yield in the subsequent year (Moatamed, 2012). In vines, the soluble solids, titratable acidity, anthocyanin content, and phenolic compounds of berries differed between pruning times during the dormancy period, or after bud-sprouting (Frioni et al., 2016).

In the region of Vacaria, RS, Brazil, pruning can still be performed at the end of the vegetative cycle, since the plants have still a considerable amount of leaves during that period. In most cases, pruning at this time is due to the great extension of the orchards, which requires it work to start early. The present study was carried out based on the fact that there are few studies on the effect of pruning times on apple trees, and that the early removal of leaves may mean the reduction of carbohydrates accumulation.

The objective of this work was to evaluate the different pruning times, performed before or after natural leaf drop, regarding their effects on the yield of 'Royal Gala' apple trees.

\section{Materials and Methods}

This experiment was carried out at the experimental station of temperate climate fruits, of Embrapa Uva e Vinho, in the municipality of Vacaria, in the state of Rio Grande do Sul $\left(28^{\circ} 33^{\prime} \mathrm{S}, 50^{\circ} 57^{\prime} \mathrm{W}\right.$, at $955 \mathrm{~m}$ altitude), Brazil, using four harvests during the period $2008 / 2009$ to $2011 / 2012$. The region has a temperate climate (Cfbl), according to Köppen-Geiger's classification. The soil of the experimental area was classified according to Santos et al. (2013) as a Latossolo Vermelho distroférrico húmico, i.e., Rhodic Hapludox.

Seven-year-old 'Royal Gala' apple trees, grafted on 'M-7' rootstocks, were used in the experiment. Trees were trained to a central leader system, and they were spaced in an area of approximately $4.0 \times 1.5 \mathrm{~m}$ $\left(1,667\right.$ trees $\left.h^{-1}\right)$.

A randomized complete block experimental design was used, with five replicates and one useful plant each. The treatments consisted of different times of pruning performed before or after natural leaf drop. For this, the date at which about $90 \%$ of leaves had dropped in each year was set visually, which happened from $18^{\text {th }}$ to $22^{\text {nd }}$ June. The pruning times were then divided into two groups: group 1 (pruning before natural leaf drop), and group 2 (pruning during the dormancy period, after leaf drop). Pruning times in group 1 were: May $5^{\text {th }}$, at 46 days before leaf drop (DBLD); May $26^{\text {th }}$ (25 DBLD); and June $15^{\text {th }}$ (5 DBLD). Pruning times in group 2 were: July $5^{\text {th }}$, at 15 days after leaf drop (DALD); July $26^{\text {th }}$ (36 DALD); August $14^{\text {th }}$ (55 DALD); and September $3^{\text {th }}$ (75 DALD).

The pruning treatments consisted of the removal of vigorous upright shoots, as well as dead or diseased branches, in order to allow of a better light distribution in the canopy. In order to maintain a consistent standard of pruning, all operations were performed annually by the same pruner. Trees used for the experiment had not been previously pruned in the summer.

The evaluated variables were: yield and number of fruit per tree, determined by weighing and counting all fruit; average fruit mass, determined by relating fruit mass to the number of fruit from each tree; cumulative yield, established by quantifying yield of each tree 
during all the four harvests; and fruit set, based on two branches from the central region of the canopy, which were identified during the 2008 dormant season. In each year, the number of flower clusters in full bloom was counted, and, subsequently, the number of fruit retained. The fruit set was determined for the 2008/2009, 2009/2010, and 2010/2011 seasons, expressed as fruit per cluster.

During the seasons 2009/2010 and 2010/2011, samples of 18 fruit by replicate were collected for the following measurements: pulp firmness, performed at two points per fruit, using a manual penetrometer with a $11 \mathrm{~mm}$ tip; content of soluble solids, which was determined using a portable analog refractometer; and titratable acidity, determined by titration with $0.1 \mathrm{~N}$ sodium hydroxide.

Data gathered at the same experimental unity, during the four-year experimental period, were analyzed as repeated measurements using Proc Mixed from SAS 9.2 statistical software (SAS Institute, Cary, NC, USA). The covariance structure with the best adjustment to each variable was selected according to Akaike's and Bayesian criteria (Silva et al., 2015). Interactions between factors were considered significant when $\mathrm{p} \leq 0.25$ (Perecin \& Cargnelutti Filho, 2008). In this case, the effect of pruning times in each year was verified. The comparison of effects of pruning times performed before leaf drop (46 DBLF, 25 DBLF, 5 DBLF) vs. pruning during dormancy (15 DALF, 36 DALF, 55 DALF, 75 DALF) was conducted using the orthogonal contrast analysis. Contrast analysis was also used to compare effects of the different pruning times before leaf drop, as follows: 46 DBLD vs. (25 DBLD, 5 DBLD)/2; and 25 DBLD vs. 5 DBLD. This was also used to compare effects of different pruning times during dormancy, as follows: 15 DALD vs. (36 DALD, 55 DALD, 75 DALD)/3; 36 DALD vs. (55 DALD, 75 DALD)/2; and 55 DALD vs. 75 DALD. Investigation of the correlation between the number of fruit per tree and the fruit set in each year, as well as the number of fruit per tree and the average fruit mass, was performed by the Pearson test using the SAS Proc GLM procedure.

\section{Results and Discussion}

Pruning at different times affected the yield of 'Royal Gala' apple trees (Table 1). In the harvests of 2008/2009,
2009/2010, and 2010/2011, the pruning performed after the natural leaf drop, still during dormancy, resulted in a higher yield per tree, in comparison to pruning times before leaf drop. However, in the 2011/2012 harvest, trees pruned after the natural leaf drop were less productive.

The decreased yield, observed in trees which had undergone pruning before leaf drop, may be linked to a reduced accumulation of reserve substances due to the decrease of the leaf area caused by pruning, which, in turn, may have caused the reduction of fructification (Loescher et al., 1990). The lowered yield observed in the harvest 2011/2012 may be attributed, in part, to the high yield of trees pruned during dormancy in the previous year, which averaged $37.5 \mathrm{~kg}$ per tree (62.5 $\mathrm{Mg} \mathrm{ha}^{-1}$ ). According to Smith \& Samach (2013), during a year of increased yield, there is generally less vegetative growth and, consequently, a decreased yield in the subsequent year. Although 'Royal Gala' is considered to be a cultivar less prone to alternate bearing (Racsko \& Miller, 2011), this explanation cannot be ruled out.

Among the pruning times before leaf drop, the 46 DBLD pruning was the one which resulted in lowest yields during the 2010/2011 and 2011/2012 harvests, in comparison to the 25 and 5 DBLD times. This finding confirms the view that pruning performed during the period preceding the end of the cycle affects the production, as a consequence of the removal of leaves still photosynthetically active, and of the loss of reserved substances stored in the shoots.

Only two differences were observed between the pruning times performed during dormancy. In the harvest of 2008/2009, the 36 DALD pruning induced higher yields than the two later times. Still, in the harvest of 2009/2010, the 15 DALD pruning caused a lower yield per tree than the 36,55 , and 75 DALD times.

Pruning times performed before leaf drop caused decreases in cumulative yield, in comparison to pruning times during dormancy (Table 1). Among the pruning times performed before leaf drop, the lowest cumulative yield was observed with 46 DBLD, in comparison to the 25 and 5 DBLD. Pruning times during dormancy resulted all in similar cumulative yield values.

Apple tree yields are influenced by environmental conditions (nutrient, light, and water availability), 
physiological processes (leaf area development, photosynthesis, and respiration), and also by management practices employed in the orchard (pruning, thinning, and disease control) (Wünsche \& Lakso, 2000). Among these management practices, the physiological response to pruning is influenced by several factors, such as cultivar, climatic conditions, and timing (Sosna, 2010; Fumey et al., 2011; Ikinci et al., 2014). The time of pruning applied during the growth cycle can affect the capacity of leaves from inside the canopy to acclimatize to the increase in PAR, which may impact on the carbohydrate accumulation in the plant. Mierowska et al. (2002), observed that, when apple trees were pruned during summer, leaves showed a fast adaptation to PAR increase. However, Li \& Lakso (2004) did not observe an increase of photosynthesis in leaves located inside the canopy as a result of mid-summer pruning and, to these authors, the leaf photosynthetic capacity after the summer pruning depends on its exposure to PAR before pruning.

The acclimatization of leaves to PAR alterations caused by pruning may vary between the apple tree cultivars, and it is influenced by environmental conditions at the moment of pruning. According to Auzmendi et al. (2013), the acclimatization capacity of apple tree leaves under PAR may vary throughout the growth cycle, it is lower after the end of the summer. Therefore, autumn pruning, at the end of the vegetative cycle, may result in a decreased carbohydrate accumulation. This occurs because there is a decrease of the leaf area, and the inner leaves of the canopy, previously shaded, tend to not respond to PAR increase caused by pruning. Furthermore, the photosynthetic activity reduces drastically between the beginning and the end of the summer due to decreases in PAR and temperature (Mierowska et al., 2002; Li \& Lakso, 2004; Auzmendi et al., 2013; Zanotelli et al., 2014).

In deciduous plants, such as the apple tree, the carbohydrate reserve levels vary during the growth cycle; they are low during the blossom period and the beginning of fructification, and high at the end of the growth season (Loescher et al., 1990). Carbohydrate accumulation occurs until the period close to leaf drop, and higher levels at this point are associated with an increased production in the following cycle. This increase is due to stored carbohydrates responsible for supplying the energy demand at the beginning of the growth cycle, when simultaneous growth of vegetative and reproductive organs occurs (Greer et al., 2002; Fanwoua et al., 2014; Melke, 2015).

The yield decrease with pruning times before natural leaf drop appears to be linked to decreases in

Table 1. Yield per tree and cumulative yield of 'Royal Gala' apple (Malus domestica) trees subjected to different pruning times, before or after leaf drop, during four seasons, in the municipality of Vacaria, in the state of Rio Grande do Sul, Brazil.

\begin{tabular}{|c|c|c|c|c|c|c|}
\hline \multirow[t]{2}{*}{ Pruning time } & \multicolumn{4}{|c|}{ Yield (kg per tree) } & \multirow{2}{*}{\multicolumn{2}{|c|}{$\begin{array}{c}\text { Cumulative yield } \\
\text { (kg per tree) }\end{array}$}} \\
\hline & $2008 / 2009$ & $2009 / 2010$ & $2010 / 2011$ & $2011 / 2012$ & & \\
\hline 46 days before leaf drop (DBLD) & 7.00 & 25.22 & 21.42 & 12.68 & \multicolumn{2}{|c|}{66.32} \\
\hline 25 days before leaf drop & 10.79 & 19.86 & 27.91 & 16.36 & \multicolumn{2}{|c|}{74.92} \\
\hline 5 days before leaf drop & 11.68 & 25.94 & 28.22 & 16.30 & \multicolumn{2}{|c|}{82.14} \\
\hline 15 days after leaf drop (DALD) & 16.05 & 24.02 & 35.84 & 11.18 & \multicolumn{2}{|c|}{87.09} \\
\hline 36 days after leaf drop & 20.67 & 32.06 & 39.66 & 10.52 & \multicolumn{2}{|c|}{102.91} \\
\hline 55 days after leaf drop & 13.09 & 31.72 & 37.98 & 9.50 & \multicolumn{2}{|c|}{92.29} \\
\hline 75 days after leaf drop & 17.95 & 26.36 & 36.45 & 13.14 & \multicolumn{2}{|c|}{93.90} \\
\hline Source of variation & F Test & $\operatorname{Pr}>F$ & & & F Test & $\operatorname{Pr}>F$ \\
\hline Time (T) & 7.50 & $<0.0001^{* *}$ & & & 6.58 & $0.003 * *$ \\
\hline Season (S) & 203.43 & $<0.0001 * *$ & & & & \\
\hline $\mathrm{T} \times \mathrm{S}$ & 5.66 & $<0.0001^{* *}$ & & & & \\
\hline Contrast & \multicolumn{6}{|c|}{ Orthogonal contrasts $(\mathrm{Pr}>\mathrm{F})$} \\
\hline $\mathrm{C} 1$, pruning BLD vs. pruning ALD & $<0.0001^{* *}$ & $0.0036^{* *}$ & $<0.0001 * *$ & $0.0004 * *$ & \multicolumn{2}{|c|}{$<0.0001 * * *$} \\
\hline $\mathrm{C} 2,46$ DBLD vs. $(25 \mathrm{DBLD}+5 \mathrm{DBLD}) / 2$ & 0.0816 & 0.3682 & $0.0177^{*}$ & $0.0324 *$ & \multicolumn{2}{|c|}{$0.0491 *$} \\
\hline C3, 25 DBLD vs. 5 DBLD & 0.7469 & $0.0445^{*}$ & 0.9215 & 0.9749 & \multicolumn{2}{|c|}{0.2993} \\
\hline $\mathrm{C} 4,15$ DALD vs. $(36$ DALD +55 DALD +75 DALD $) / 3$ & 0.5984 & $0.0156^{*}$ & 0.3906 & 0.9352 & \multicolumn{2}{|c|}{0.1078} \\
\hline C5, 36 DALD vs. (55 DALD + 75 DALD)/2 & $0.0357 *$ & 0.2427 & 0.3658 & 0.6290 & \multicolumn{2}{|c|}{0.1086} \\
\hline C6, 55 DALD vs. 75 DALD & 0.0838 & 0.0752 & 0.6237 & 0.0626 & \multicolumn{2}{|c|}{0.8155} \\
\hline
\end{tabular}

$*, * *, * * *$ Significant at 5,1 and, $0.01 \%$ probability. 
fruit set, according to positive correlations between fruit set and the number of fruit per tree were observed in three harvests (Figure 1 A). In deciduous plants, such as apple trees, stresses occurring at the end of the vegetative cycle which reduce the leaf area - caused either by disease or by leaf removal through pruning - may reduce storage of reserves in perennial organs, and impact negatively on the performance in the subsequent cycle (Loescher et al., 1990; Melke, 2015). In pear trees, late summer pruning times reduced fructification in the subsequent harvest (Moatamed, 2012).

There were differences for the fruit set in the comparison of pruning before leaf drop and pruning during dormancy (Table 2). In the harvests of 2008/2009 and 2010/2011, trees pruned before leaf drop displayed
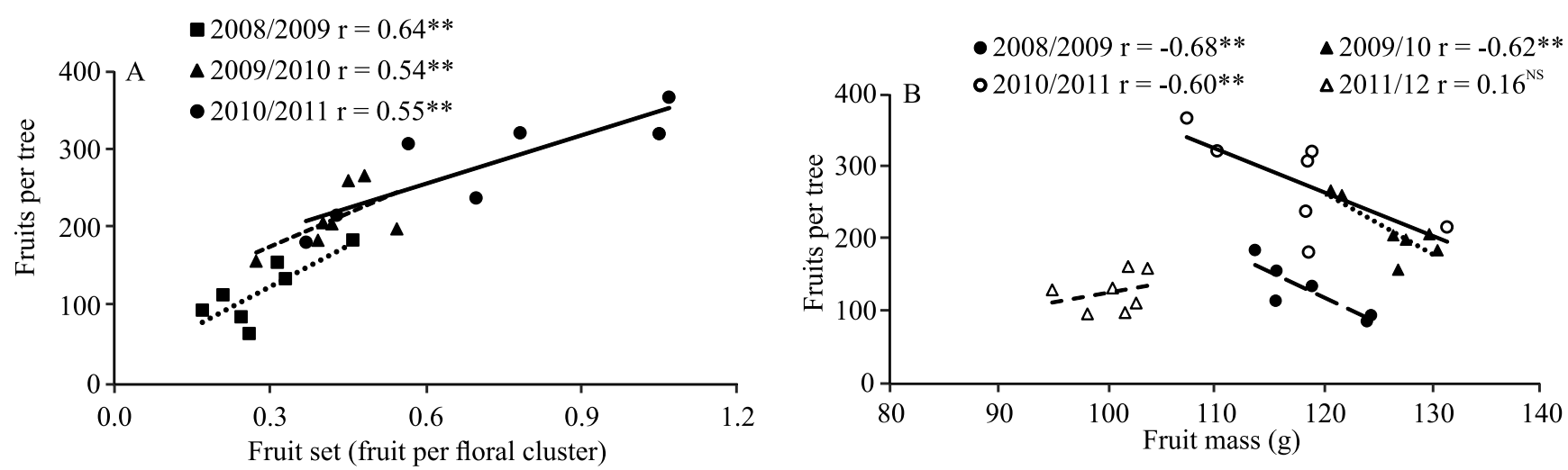

Figure 1. Pearson correlation analysis between fruit set (A) and average fruit mass (B) with the number of fruit per tree of

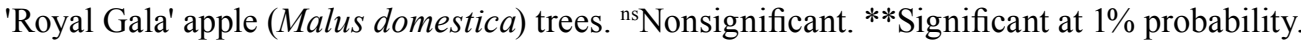

Table 2. Fruit set and fruit mass of 'Royal Gala' apple (Malus domestica) trees subjected to different pruning times, before or after leaf drop, in the municipality of Vacaria, in the state of Rio Grande do Sul, Brazil.

\begin{tabular}{|c|c|c|c|c|c|c|c|}
\hline \multirow[t]{2}{*}{ Pruning } & \multicolumn{3}{|c|}{ Fruit set (fruit or flower per cluster) } & \multicolumn{4}{|c|}{ Fruit mass $(\mathrm{g})$} \\
\hline & $2008 / 2009$ & $2009 / 2010$ & $2010 / 2011$ & $2008 / 2009$ & $2009 / 2010$ & $2010 / 2011$ & $2011 / 2012$ \\
\hline 46 days before leaf drop (DBLD) & 0.26 & 0.54 & 0.37 & 108.8 & 127.7 & 118.7 & 95.0 \\
\hline 25 days before leaf drop & 0.24 & 0.27 & 0.43 & 124.0 & 126.9 & 131.4 & 103.8 \\
\hline 5 days before leaf drop & 0.17 & 0.42 & 0.70 & 124.4 & 126.5 & 118.4 & 102.0 \\
\hline 15 days after leaf drop (DALD) & 0.33 & 0.39 & 0.78 & 119.0 & 130.6 & 110.2 & 102.8 \\
\hline 36 days after leaf drop & 0.46 & 0.48 & 1.07 & 113.7 & 120.7 & 107.4 & 101.7 \\
\hline 55 days after leaf drop & 0.21 & 0.45 & 1.05 & 115.6 & 121.7 & 119.0 & 98.3 \\
\hline 75 days after leaf drop & 0.31 & 0.40 & 0.57 & 115.7 & 129.8 & 118.6 & 100.6 \\
\hline$\underline{\text { Source of variation }}$ & $\mathrm{F}$ test & & & $\operatorname{Pr}>\mathrm{F}$ & & & \\
\hline Time $(\mathrm{T})$ & 0.055 & & & $0.039^{*}$ & & & \\
\hline Season (S) & $<.001^{* *}$ & & & $<0.001^{* *}$ & & & \\
\hline \multirow[t]{2}{*}{$\underline{\mathrm{T} x \mathrm{~S}}$} & $0.001 * *$ & & & $0.009^{* *}$ & & & \\
\hline & \multicolumn{7}{|c|}{ Orthogonal contrasts $(\mathrm{Pr}>\mathrm{F})$} \\
\hline $\mathrm{C} 1$, pruning BLD vs. pruning ALD & $0.040^{*}$ & 0.782 & $0.001^{* *}$ & 0.171 & 0.668 & $0.005^{* *}$ & 0.801 \\
\hline $\mathrm{C} 2,46$ DBLD vs. $(25$ DBLD +5 DBLD $) / 2$ & 0.443 & 0.090 & 0.245 & $<0.001^{* *}$ & 0.845 & 0.209 & $0.029 *$ \\
\hline C3, 25 DBLD vs. 5 DBLD & 0.395 & 0.272 & 0.165 & 0.926 & 0.936 & $0.025^{*}$ & 0.656 \\
\hline C4, 15 DALD vs. $(36$ DALD + 55 DALD + 75 DALD $) / 3$ & 0.985 & 0.622 & 0.467 & 0.240 & 0.166 & 0.306 & 0.439 \\
\hline C5, 36 DALD vs. (55 DALD + 75 DALD)/2 & $0.012 * *$ & 0.624 & 0.121 & 0.584 & 0.304 & $0.025^{*}$ & 0.512 \\
\hline C6, 55 DALD vs. 75 DALD & 0.270 & 0.710 & $0.016^{*}$ & 0.983 & 0.159 & 0.941 & 0.567 \\
\hline
\end{tabular}

*,**Significant at 5 and $1 \%$ probability. 
a lower effective fructification. Another difference was apparent among pruning times during dormancy, where 75 DALD pruning, which is few days before bud burst, resulted in lower fructification. At this stage of the growth cycle, physiological processes that precede bud burst, such as mobilization and transport of carbohydrates from storage organs towards the meristems, may already be initiated (Loescher et al., 1990). As a consequence, the part of the meristem removed by pruning will probably have already consumed the carbohydrate and nitrogen reserves, reducing their availability for the other plant organs.

The effect of autumn pruning times on the yield from apple trees is still poorly documented. Published research on the evaluation of pruning times in apple trees involves mainly pruning in summer and during dormancy (Autio \& Greene, 1990; Bound \& Summers, 2001).

Average fruit mass was affected by pruning times (Table 2). The pruning times during dormancy resulted in a lower-average fruit mass than pruning times before leaf drop, but it happened in 2010/2011 only. The biggest difference in fruit mass was observed when pruning times before leaf drop were compared, and that performed at 46 DBLD provided the smaller fruit, in the harvests 2008/2009 and 2011/2012.

Among the pruning times during dormancy, a difference was only observed at the harvest of 2010/2011, where pruning at 36 DALD induced smaller fruit.

Differences observed in average fruit mass were mostly due to the effect of different pruning times on the number of fruit per tree, as the number of fruits per tree showed a negative correlation with fruit mass in all three harvests (Figure $1 \mathrm{~B}$ ). However, in the harvests with low production (2008/2009 and 2011/2012), trees pruned at 46 DBLD showed low yield and also fruit of a lower-average mass. Due to low-fruit load per tree, the growth of shoots can be stimulated, as observed by Castro et al. (2015), which leads to competition for carbohydrates and impairment of fruit growth (Lakso \& Goffinet, 2013).

Qualitative and fruit ripening aspects were also affected by pruning times (Table 3). Pruning before leaf drop in 2009/2010 induced a higher-pulp firmness, higher content of soluble solids, higher titratable acidity and lower-soluble solids/titratable acidity ratio, in comparison to pruning during dormancy. Among

Table 3. Pulp firmness (PF), soluble solids (SS), titratable acidity (TA), and soluble solids/titratable acidity relation (SS/ TA) of fruit of 'Royal Gala' apple (Malus domestica) trees subjected to different pruning times, during four seasons, in the municipality of Vacaria, in the state of Rio Grande do Sul, Brazil.

\begin{tabular}{|c|c|c|c|c|c|c|c|c|}
\hline \multirow[t]{2}{*}{ Pruning } & \multicolumn{2}{|c|}{ Pulp firmness $(\mathrm{N})$} & \multicolumn{2}{|c|}{ Soluble solids ( ${ }^{\circ}$ Brix) } & \multicolumn{2}{|c|}{ Titratable acidity } & \multicolumn{2}{|c|}{$\mathrm{SS} / \mathrm{TA}$ relation } \\
\hline & $2009 / 2010$ & $2010 / 2011$ & $2009 / 2010$ & $2010 / 2011$ & $2009 / 2010$ & $2010 / 2011$ & $2009 / 2010$ & $2010 / 2011$ \\
\hline 46 days before leaf drop (DBLD) & 58.9 & 49.5 & 12.1 & 12.7 & 0.39 & 0.28 & 30.7 & 44.5 \\
\hline 25 days before leaf drop & 53.4 & 48.2 & 11.7 & 12.8 & 0.36 & 0.30 & 32.5 & 42.9 \\
\hline 5 days before leaf drop & 48.9 & 47.4 & 11.5 & 12.7 & 0.33 & 0.28 & 34.5 & 45.9 \\
\hline 15 days after leaf drop (DALD) & 51.2 & 46.9 & 11.4 & 12.9 & 0.30 & 0.29 & 38.2 & 45.1 \\
\hline 36 days after leaf drop & 48.6 & 44.7 & 11.3 & 12.3 & 0.29 & 0.27 & 39.4 & 45.3 \\
\hline 55 days after leaf drop & 47.0 & 46.9 & 11.5 & 12.7 & 0.31 & 0.27 & 37.4 & 47.6 \\
\hline 75 days after leaf drop & 49.7 & 48.1 & 11.5 & 12.9 & 0.32 & 0.29 & 35.8 & 44.9 \\
\hline$\underline{\text { Source of variation }}$ & F test & & $\operatorname{Pr}>\mathrm{F}$ & & $\operatorname{Pr}>\mathrm{F}$ & & $\operatorname{Pr}>\mathrm{F}$ & \\
\hline Time $(\mathrm{T})$ & $<0.001 * *$ & & $0.040 *$ & & $<0.001 * *$ & & $<0.001^{* *}$ & \\
\hline Season $(\mathrm{S})$ & $<0.001 * *$ & & $<0.001 * *$ & & $<0.001^{* *}$ & & $<0.001 * *$ & \\
\hline $\mathrm{T} \times \mathrm{S}$ & $0.004^{* *}$ & & $0.085^{+}$ & & $0.005^{* *}$ & & $0.156^{+}$ & \\
\hline Contrast & \multicolumn{8}{|c|}{ Orthogonal contrasts $(\mathrm{Pr}>\mathrm{F})$} \\
\hline $\mathrm{C} 1$, pruning BLD vs. pruning ALD & $<0.001 * *$ & 0.054 & $<0.001^{* *}$ & 0.786 & $<0.001 * *$ & 0.259 & $<0.001^{* *}$ & 0.207 \\
\hline $\mathrm{C} 2,46 \mathrm{DBLD}$ vs. $(25 \mathrm{DBLD}+5 \mathrm{DBLD}) / 2$ & $<0.001 * *$ & 0.230 & $0.003 * *$ & 0.584 & $0.001 * *$ & 0.692 & 0.063 & 0.980 \\
\hline C3, 25 DBLD vs. 5 DBLD & $0.008 * *$ & 0.628 & 0.571 & 0.703 & 0.098 & 0.182 & 0.212 & 0.112 \\
\hline $\mathrm{C} 4,15$ DALD vs. $(36 \mathrm{DALD}+55 \mathrm{DALD}+75 \mathrm{DALD}) / 3$ & 0.056 & 0.750 & 0.979 & 0.305 & 0.964 & 0.421 & 0.948 & 0.590 \\
\hline C5, 36 DALD vs. (55 DALD + 75 DALD)/2 & 0.852 & $0.046^{*}$ & 0.208 & $0.015 *$ & 0.149 & 0.601 & 0.220 & 0.563 \\
\hline C6, 55 DALD vs. 75 DALD & 0.174 & 0.454 & 0.955 & 0.453 & 0.325 & 0.220 & 0.255 & 0.169 \\
\hline
\end{tabular}

*,**Significant at 5 and $1 \%$ probability. ${ }^{+}$Interaction significant at less than $25 \%$ probability. 
the pruning times before leaf drop, the earlier pruning time (46 DBLD) also resulted in the highest values for pulp firmness, soluble solids, and titratable acidity. Among pruning times during dormancy, 36 DALD resulted in the lowest values for pulp firmness and soluble solids.

Changes in the qualitative characteristics of the fruit appeared to be a consequence of the effect of pruning on the bud burst period and on fruit load. Pruning of plants which still had leaves, mainly at 46 and 25 DBLD, showed a 6-day delay in bud burst in the subsequent year (data not shown) than plants pruned during dormancy. This cycle delay appeared to lead to a delay in the fruit ripening period, which explains the increase of pulp firmness and titratable acidity. However, the increase of the content of soluble solids, associated with pruning before leaf drop, seems to be a consequence of the observed lower-fruit load per tree, which is in accordance with Meland (2009).

\section{Conclusions}

1. Pruning of 'Royal Gala' apple trees in the autumn, during the period preceding the natural leaf drop, reduces the fruit set, and results in lower yields of fruit.

2. The pruning performed during dormancy results in a higher yield per tree than pruning times before leaf drop.

\section{Acknowledgments}

To Conselho Nacional de Desenvolvimento Científico e Tecnológico (CNPq), for scholarship granted.

\section{References}

ASHRAF, N.; ASHRAF, M. Summer pruning in fruit trees. African Journal of Agricultural Research, v.9, p.206-210, 2014. DOI: 10.5897/AJAR2013.7916.

AUTIO, W.R.; GREENE, D.W. Summer pruning affects yield and improves fruit quality of 'McIntosh' apples. Journal of the American Society for Horticultural Science, v.115, p.356-359, 1990.

AUZMENDI, I.; MARSAL, J.; GIRONA, J.; LOPEZ, G. Daily photosynthetic radiation use efficiency for apple and pear leaves: seasonal changes and estimation of canopy net carbon exchange rate. European Journal of Agronomy, v.51, p.1-8, 2013. DOI: 10.1016/j.eja.2013.05.007.
BOUND, S.A.; SUMMERS, C.R. The effect of pruning level and timing on fruit quality in red 'Fuji' apple. Acta Horticulturae, v.557, p.295-302, 2001. DOI: 10.17660/ActaHortic.2001.557.38.

CASTRO, D.C.; ÁlVAREZ, N.; GABRIEL, P.; MICHELOUD, N.; BUYATTI, M.; GARIGLIO, N. Crop loading studies on 'Caricia' and 'Eva' apples grown in a mild winter area. Scientia Agricola, v.72, p.237-244, 2015. DOI: 10.1590/0103-9016-20140267.

DEMIRTAS, M.N.; BOLAT, I.; ERCISLI, S.; IKINCI, A.; OLMEZ, H.A.; SAHIN, M.; ALTINDAG, M.; CELIK, B. The effects of different pruning treatments on the growth, fruit quality and yield of 'Hacihaliloglu' apricot. Acta Scientiarun Polonorum, Hortorum Cultus, v.9, p.183-192, 2010.

FANWOUA, J.; BAIRAM, E.; DELAIRE, M.; BUCK-SORLIN, $\mathrm{G}$. The role of branch architecture in assimilate production and partitioning: the example of apple (Malus domestica). Frontiers in Plant Science, v.5, p.1-6, 2014. DOI: 10.3389/fpls.2014.00338.

FRIONI, T.; TOMBES, S.; SILVESTRONI, O.; LANARI, V.; BELliCONTRO, A.; SABBATINI, P.; GATTI, M.; PONI, S.; PALLIOTTI, A. Postbudburst spur pruning reduces yield and delays fruit sugar accumulation in cv. Sangiovese in central Italy. American Journal of Enology and Viticulture, v.67, p.419-425, 2016. DOI: 10.5344/ajev.2016.15120.

FUMEY, D.; LAURI, P.E.; GUEDON, Y.; GODIN, C.; COSTES, E. How young trees cope with removal of whole or parts of shoots: an analysis of local and distant responses to pruning in 1-year-old apple (Malus $\times$ domestica; Rosaceae) trees. American Journal of Botany, v.98, p.1737-1751, 2011. DOI: 10.3732/ajb.1000231.

GONÇALVES, M.A.; PICOLOTTO, L.; AZEVEDO, F.Q.; COCCO, C.; ANTUNES, L.E.C. Qualidade de fruto e produtividade de pessegueiros submetidos a diferentes épocas de poda. Ciência Rural, v.44, p.1334-1340, 2014. DOI: 10.1590/0103$8478 \mathrm{cr} 20120617$.

GREER, D.H.; WÜNSCHE, J.N.; HALLIGAN, E.A. Influence of postharvest temperatures on leaf gas exchange, carbohydrate reserves and allocations, subsequent bud break and fruit yield of 'Braeburn' apple (Malus domestica) trees. New Zealand Journal of Crop and Horticultural Science, v.30, p.175-185, 2002. DOI: 10.1080/01140671.2002.9514213.

IKINCI, A. Influence of pre- and postharvest summer pruning on the growth, yield, fruit quality, and carbohydrate content of early season peach cultivars. The Scientific World Journal, v. 2014, article ID 104865, 2014. DOI: 10.1155/2014/104865.

IKINCI, A.; KUDEN, A.; AK, B.E. Effects of summer and dormant pruning time on the vegetative growth, yield, fruit quality and carbohydrate contents of two peach cultivars. African Journal of Biotechnology, v.13, p.84-90, 2014. DOI: 10.5897/ AJB09.1614.

LAKSO, A.N.; GOFFINET, M.C. Apple fruit growth. New York Fruit Quarterly, v.21, p.11-14, 2013.

LI, K.-T.; LAKSO, A.N. Photosynthetic characteristics of apple spur leaves after summer pruning to improve exposure to light. HortScience, v.39, p.969-972, 2004.

Pesq. agropec. bras., Brasília, v.53, n.4, p.427-434, Abr. 2018 DOI: $10.1590 / \mathrm{S} 0100-204 \mathrm{X} 2018000400004$ 
LI, K.-T.; LAKSO, A.N.; PICCIONI, R.; ROBINSON, T. Summer pruning effects on fruit size, fruit quality, return bloom and fine root survival in apple trees. The Journal of Horticultural Science and Biotechnology, v.78, p.755-761, 2003. DOI: 10.1080/14620316.2003.11511695.

LOESCHER, W.H.; MCCAMANT, T.; KELLER, J.D. Carbohydrate reserves, translocation, and storage in woody plant roots. Hortscience, v.25, p.274-281, 1990.

MELAND, M. Effects of different crop loads and thinning times on yield, fruit quality, and return bloom in Malus $\mathrm{x}$ domestica Borkh. 'Elstar'. The Journal of Horticultural Science and Biotechnology, v.84, p.117-121, 2009. DOI: 10.1080/14620316.2009.11512607.

MELKE, A. The physiology of chilling temperature requirements for dormancy release and bud-break in temperate fruit trees grown at mild winter tropical climate. Journal of Plant Studies, v.4, p.110-156, 2015. DOI: 10.5539/jps.v4n2p110.

MIEROWSKA, A.; KEUTGEN, N.; HUYSAMER, M.; SMITH, V. Photosynthetic acclimation of apple spur leaves to summer pruning. Scientia Horticulturae, v.92, p.9-27, 2002. DOI: 10.1016/S0304-4238(01)00275-8.

MOATAMED, A.M.H. Effect of summer pruning on vegetative growth, yield and fruit quality of 'Le-Conte' pear trees. Journal of American Science, v.8, p.640-647, 2012.

MOHAMMADI, A.; MAHMOUDI, M.J.; REZAEE, R. Vegetative and reproductive responses of some apple cultivars (Malus domestica Borkh.) to heading back pruning. International Journal of AgriScience, v.3, p.628-635, 2013.

PERECIN, D.; CARGNELUTTI FILHO, A. Efeitos por comparações e por experimento em interações de experimentos fatoriais. Ciência e Agrotecnologia, v.32, p.68-72, 2008. DOI: 10.1590/S1413-70542008000100010.

RACSKO, J.; MILLER, D.D. Effect of different growth inducing rootstocks on alternate bearing of 'Royal Gala' and 'Vista Bella' apples. Acta Horticulturae, v.903, p.411-418, 2011. DOI: 10.17660/ActaHortic.2011.903.54.

SANTOS, H.G. dos; JACOMINE, P.K.T.; ANJOS, L.H.C. dos; OLIVEIRA, V.A. de; LUMBRERAS, J.F.; COELHO, M.R.; ALMEIDA, J.A. de; CUNHA, T.J.F.; OLIVEIRA, J.B. de. Sistema brasileiro de classificação de solos. 3.ed. rev. e ampl. Brasília: Embrapa, 2013. 353p.

SILVA, E.N.; DUARTE, J.B.; REIS, A.J. dos S. Seleção da matriz de variância-covariância residual na análise de ensaios varietais com medidas repetidas em cana-de-açúcar. Ciência Rural, v.45, p.993-999, 2015. DOI: 10.1590/0103-8478cr20141531.

SMITH, H.M.; SAMACH, A. Constraints to obtaining consistent annual yields in perennial tree crops. I: heavy fruit load dominates over vegetative growth. Plant Science, v.207, p.158-167, 2013. DOI: 10.1016/j.plantsci.2013.02.014.

SOSNA, I. Effect of pruning time on growth, blooming and content of chemical constituents in leaves of four early ripening plum cultivars. Journal of Fruit and Ornamental Plant Research, v.18, p.151-160, 2010.

WÜNSCHE, J.N.; LAKSO, A.N. Apple tree physiology: implications for orchard and tree management. Compact Fruit Tree, v.33, p.82-88, 2000.

ZANOTELLI, D.; MONTAGNANI, L.; MANCA, G.; SCANDELLARI, F.; TAGLIAVINI, M. Net ecosystem carbon balance of an apple orchard. European Journal of Agronomy, v.63, p.97-104, 2014. DOI: 10.1016/j.eja.2014.12.002.

Received on March 23, 2017 and accepted on July 28, 2017 